\title{
Identification of enteropathogenic Escherichia coli isolated in Britain as enteroaggregative or as members of a subclass of attaching-and-effacing $E$. coli not hybridising with the EPEC adherence-factor probe
}

\author{
S. M. SCOTLAND, H. R. SMITH, B. SAID, G. A. WILLSHAW, T. CHEASTY and B. ROWE
}

Division of Enteric Pathogens, Central Public Health Laboratory, 61 Colindale Avenue, London NW9 5HT

\begin{abstract}
Summary. Strains of Escherichia coli from sporadic cases of diarrhoea and belonging to serotypes $\mathrm{O} 44: \mathrm{H} 18, \mathrm{O} 55: \mathrm{H} 7, \mathrm{O} 111 a b: \mathrm{H} 21, \mathrm{O} 111 a b: \mathrm{H} 25$ or $\mathrm{O} 126: \mathrm{H} 27$ were examined for virulence properties. With the exception of $\mathrm{O} 111 \mathrm{ab}: \mathrm{H} 25$ these are considered to be classical enteropathogenic E. coli (EPEC) serotypes. The strains had been isolated in Britain from the faeces of children $<3$ years old. Of the serotypes examined, 7 of 13 O44:H18 strains, all of $10 \mathrm{O} 111 \mathrm{ab}: \mathrm{H} 21$ strains and 13 of $21 \mathrm{O} 126: \mathrm{H} 27$ strains belonged to the enteroaggregative class of E. coli (EAggEC) that attached to HEp-2 cells in the characteristic aggregative pattern and hybridised with the EAggEC probe. They also caused mannose-resistant haemagglutination of rat erythrocytes, a property which may be a useful marker for their identification. Strains of $\mathrm{O} 44: \mathrm{H} 18$ with similar properties were also isolated from three small outbreaks in Britain, one of which involved elderly patients. EAggEC have not been considered previously as aetiological agents of diarrhoea in developed countries and have rarely been reported as belonging to EPEC serotypes. All 15 O55:H7 strains and seven of eight $\mathrm{O} 111 \mathrm{ab}: \mathrm{H} 25$ strains were also considered to be potentially diarrhoeagenic as they gave localised attachment (LA) to HEp-2 cells that resulted in a positive fluorescence actinstaining test. This test is considered to correlate with the attaching-and-effacing virulence mechanisms of EPEC in vivo. None of the strains in this study hybridised with the EPEC adherence-factor (EAF) probe. Neither the aggregative EPEC nor the LA-positive EAFnegative EPEC described here would be identified in epidemiological surveys when the EAF probe is used in the absence of cell tests.
\end{abstract}

\section{Introduction}

Some classes of Escherichia coli causing diarrhoea in man possess well-characterised virulence properties such as production of heat-labile enterotoxin (LT), heat-stable enterotoxin $\left(\mathrm{ST}_{\mathrm{A}}\right)$ or Vero cytotoxin (VT). For the enteropathogenic E. coli(EPEC), the virulence mechanisms are less clear. In most clinical laboratories, EPEC are identified because they belong to certain $O$ serogroups that have been associated with outbreaks of infantile diarrhoea and it is probable that only a proportion of strains belonging to these $\mathrm{O}$ serogroups are virulent. ${ }^{1}$ Strains of $E$. coli have been characterised by the pattern of their attachment to tissue-culture cells that can be localised (LA), diffuse (DA) or aggregative (AggA) ${ }^{2-4}$ LA has been shown to be an important property of EPEC. ${ }^{2,5,6}$ An LApositive strain E2348/69 (E. coli O127:H6) was confirmed as diarrhoeagenic in human-volunteer

Received 2 Feb. 1991 ; accepted 5 March 1991. studies and in this strain a particular plasmid was necessary for full virulence and for good LA. ${ }^{5,7}$ A $1-\mathrm{kb}$ probe, the EPEC adherence-factor (EAF) probe developed from this plasmid, ${ }^{8}$ has been used in a few laboratories for epidemiological studies as a means of recognising pathogenic strains.

We have used the EAF probe to examine strains belonging to 13 different EPEC serogroups and isolated from cases of diarrhoea in Britain $;{ }^{9}$ only 23 of 353 strains hybridised with the EAF probe. It was noted that the EAF-positive strains did not include strains of serotypes $\mathrm{O} 44: \mathrm{H} 18, \mathrm{O} 55: \mathrm{H} 7, \mathrm{O} 111 a b: \mathrm{H} 21$, $\mathrm{O} 111 \mathrm{ab}: \mathrm{H} 25$ and $\mathrm{O} 126: \mathrm{H} 27$ which accounted for $20 \%$ of the EPEC strains examined. With the exception of $\mathrm{O} 111 a b: \mathrm{H} 25$, these serotypes are included in the list of classical EPEC serotypes. ${ }^{1}$ Strains belonging to these five serotypes have now been characterised further with respect to other putative virulence factors that have been described for diarrhoeagenic $E$. coli.

In EPEC infections large numbers of bacteria attach to the small intestine. There can be localised 
destruction (or effacement) of the microvilli and bacteria causing these lesions have been called attaching and effacing $E$. coli (AEEC).${ }^{10}$ AEEC affect the status of actin in infected tissue-culture cells and this can be visualised in the fluorescence actin-staining (FAS) test. ${ }^{11}$ To date only strains giving LA have been shown to give positive results in the FAS test ${ }^{11,12}$ but these include strains that hybridise with the EAF probe and others that do not. For example, strains of EPEC serogroup O128 giving LA may be EAFpositive $^{6,13,14}$ or EAF-negative $\mathrm{e}^{14}$ and, as both classes are positive in the FAS test, both are probably AEEC. Most strains of O26:H11, which is considered an EPEC serotype, are EAF-negative but LA-positive and FAS-positive, and so are probably also AEEC. ${ }^{12}$ Thus, there exists a subclass (or subclasses) of AEEC comprising strains that are EAF-negative. We have examined strains of $\mathrm{O} 44: \mathrm{H} 18, \mathrm{O} 55: \mathrm{H} 7, \mathrm{O} 111 a b: \mathrm{H} 21$, $\mathrm{O} 111 \mathrm{ab}: \mathrm{H} 25$ and $\mathrm{O} 126: \mathrm{H} 27$ for their pattern of attachment to tissue-culture cells and for their reaction in the FAS test.

The role of $E$. coli giving an aggregative pattern of attachment to tissue-culture cells (EAggEC) in diarrhoea has been a matter of some controversy. They have been associated with diarrhoea in children in India where the number of isolations was significantly greater from cases than from controls. ${ }^{15,16}$ In contrast, cases and controls yielded similar numbers in studies in Brazil and Chile. ${ }^{17,18}$ These differences may in part be due to the difficulties reported in the assessment of attachment as LA, AggA or DA in tissue-culture tests. Different test procedures have been used and Vial $e t$ al. ${ }^{19}$ concluded that recognition of the aggregative pattern is best with an initial incubation period of $3 \mathrm{~h}$ rather than a $30-$ min period. We have always used the 3-h initial incubation period and have also found it advantageous to include a second 3 -h incubation period for the easy identification of some groups of LA-positive strains. ${ }^{12,14} \mathrm{~A}$ probe has been developed to detect $\mathrm{EAggEC}^{20}$ and, in addition to determining the pattern of attachment of the strains in the present study, they were also tested for hybridisation with this probe.

\section{Materials and methods}

\section{Bacterial strains}

For the main study, the strains of $E$. coli were isolates from sporadic cases of diarrhoea in Britain since 1985 and belonged to serotypes $\mathrm{O} 44: \mathrm{H} 18$, $\mathrm{O} 55: \mathrm{H} 7, \mathrm{O} 111 a b: \mathrm{H} 21, \mathrm{O} 111 a b: \mathrm{H} 25$ and $\mathrm{O} 126: \mathrm{H} 27$. All were isolated from the faeces of children $<3$ years old. The numbers of each serotype are shown in table I. Additional strains belonging to these serotypes from our culture collection that had been isolated from outbreaks of diarrhoea were also tested.

For comparison, the adhesive properties of strains from the faeces of 32 healthy children were deter- mined. A representative of each serotype excreted by the child was tested and there were 50 strains belonging to 40 different serotypes. All strains that adhered to HEp-2 cells ie tested for hybridisation with the EAggEC probe.

\section{Adhesion and fluorescence actin-staining tests}

The strains were tested for attachment in the presence of D-mannose $1 \% \mathrm{w} / \mathrm{v}$ to HEp- 2 cells in a 6-h test at $37^{\circ} \mathrm{C}$ as described before; ${ }^{21}$ the cells were washed after the first 3-h incubation period. At least 100 cells were examined and the pattern of attachment assessed as LA, AggA or DA. For the FAS test the procedure of Knutton et al. was followed in which the cell monolayer was fixed, permeabilised and treated with fluorescein isothiocyanate (FITC)-labelled phalloidin at the end of the 6-h test. ${ }^{11}$ The monolayer was then examined for areas of intense fluorescence; their position was compared by phase-contrast microscopy with that of attached bacteria.

\section{Haemagglutination tests}

The strains were tested for agglutination of bovine, guinea-pig, human and rat erythrocytes. ${ }^{21}$ For these tests, strains were grown on Mueller-Hinton agar or subcultured twice in Mueller-Hinton broth. Agglutination that occurred in the presence of mannose $0.5 \%$ was recorded as mannose-resistant haemagglutination (MRHA) and agglutination that was inhibited by the presence of mannose as mannose-sensitive haemagglutination (MSHA). Strains were also tested after growth on colonisation factor antigen agar containing bile salts $1.5 \% \mathrm{w} / \mathrm{v},{ }^{22}$ which has been used for optimal expression of haemagglutinins of enterotoxigenic $E$. coli, but the haemagglutination of strains in this study was poorer than that of strains grown on MuellerHinton agar and the results are not given.

\section{DNA-hybridisation tests}

DNA-hybridisation tests were performed under stringent conditions as described before. ${ }^{23}$ The EAF probe was a 1-kb SalI-BamHI fragment. ${ }^{8}$ The VT1 and VT2 probes were $0.75-\mathrm{kb}$ HincII and $0.85-\mathrm{kb}$ AvaI-PstI fragments, respectively. ${ }^{24}$ These probes were labelled with deoxyadenosine $5^{\prime}-\alpha-\left[{ }^{35} S\right]$ thiotriphosphate. Some EAF- and VT-probe hybridisation results have been reported in an earlier paper. ${ }^{9}$ The EAggEC probe was a $1-\mathrm{kb} E c o \mathrm{RI}-P$ st I fragment ${ }^{20}$ labelled with digoxigenin-dUTP. ${ }^{25}$ Non-radioactive alkaline phosphatase-labelled synthetic oligonucleotide probes were used to detect $\mathrm{ST}_{\mathrm{A}}$ and $\mathrm{LT}$ genes according to the manufacturer's protocols (SNAP hybridisation system, Dupont); the ST probe comprised $\mathrm{ST}_{\mathrm{A} 1}$ and $\mathrm{ST}_{\mathrm{A} 2}$ sequences (at our request). ${ }^{26}$ 
Table I. Properties of E. coli from sporadic cases of infant diarrhoea

\begin{tabular}{|c|c|c|c|c|c|c|}
\hline \multirow{3}{*}{ Serotype } & \multirow{3}{*}{$\begin{array}{l}\text { Number of } \\
\text { strains }\end{array}$} & \multirow{3}{*}{$\begin{array}{l}\text { Number of strains } \\
\text { adhering to HEp-2 cells }\end{array}$} & \multicolumn{4}{|c|}{ Properties of adherent strains } \\
\hline & & & \multirow{2}{*}{$\begin{array}{l}\text { Pattern of } \\
\text { adherence }\end{array}$} & \multicolumn{2}{|c|}{ Hybridisation with } & \multirow{2}{*}{$\begin{array}{r}\text { FAS } \\
\text { test }\end{array}$} \\
\hline & & & & $\begin{array}{l}\text { EAF } \\
\text { probe }\end{array}$ & $\begin{array}{l}\text { EAggEC } \\
\text { probe }\end{array}$ & \\
\hline O44:H18 & 13 & 7 & AggA & - & + & - \\
\hline $\mathrm{O} 111 a b: \mathrm{H} 21$ & 10 & 10 & AggA & - & + & - \\
\hline $\mathrm{O} 126: \mathrm{H} 27$ & 21 & 13 & AggA & - & + & - \\
\hline $\mathrm{O} 55: \mathrm{H} 7$ & 15 & 15 & LA & - & - & + \\
\hline $\mathrm{O} 111 a b: \mathrm{H} 25$ & 8 & 7 & LA & - & - & + \\
\hline
\end{tabular}

AggA, aggregative pattern; LA, localised pattern.

FAS test, fluorescence actin-staining test.

\section{Results}

\section{Strains giving localised attachment}

Strains from sporadic cases of diarrhoea giving localised attachment were found in serotypes O55: $\mathrm{H} 7$ and O111ab:H25 (table I). The strains did not hybridise with the EAF probe (or with EAggEC, ST, LT and VT probes). For two strains of E. coli $\mathrm{O} 55: \mathrm{H} 7$, the percentage of cells with attaching bacteria was $16 \%$ and $29 \%$; for the remaining 13 strains the percentage ranged from 40 to 100 , with a mean of 60 . For all strains the clumps of bacteria usually contained $>50$ bacteria. Outbreak-associated E. coli $\mathrm{O} 55: \mathrm{H} 7$ strains were isolated from one of three infants with diarrhoea in one hospital in 1979 and from two of three babies with diarrhoea in a second hospital in the same year. A faecal specimen from the asymptomatic mother of one baby who was excreting also yielded the organism. All these outbreak-related strains were LA-positive, attaching to $>52 \%$ cells, but EAFnegative. In contrast, only one of the O111ab:H25 strains from sporadic cases of diarrhoea adhered in large numbers to many HEp- 2 cells $(72 \%)$. The other six strains adhered to between $1 \%$ and $11 \%$ of cells, with a mean of $6 \%$; bacteria were present in localised clumps of usually $<10$ bacteria. A similar pattern of attachment was given by $E$. coli $\mathrm{O} 111 a b: \mathrm{H} 25$ strains isolated from two neonates in a special-care baby unit in 1984. Although the numbers of attaching bacteria differed, the localised attachment of bacteria of both serotypes $\mathrm{O} 55: \mathrm{H} 7$ and $\mathrm{O} 111 a b: \mathrm{H} 25$ resulted in intense fluorescence in the FAS test.

\section{Strains giving aggregative attachment}

Strains from sporadic cases of diarrhoea giving an aggregative pattern of attachment were found in serotypes $044: \mathrm{H} 18, \mathrm{O} 111 \mathrm{ab}: \mathrm{H} 21$ and $\mathrm{O} 126: \mathrm{H} 27$ (table I). All aggregative strains hybridised with the EAggEC probe (but not with the EAF, ST, LT and VT probes). The strains were negative in the FAS test. Aggregative E. coli $\mathrm{O} 44: \mathrm{H} 18$ strains with similar properties were also isolated from: (i) four infants (one with bloody diarrhoea and one with non-bloody diarrhoea) in a children's hospital in 1984; (ii) from nine children (three with diarrhoea) and four staff members in a day nursery in 1980; and (iii) from five elderly patients (all $>68$ years) with diarrhoea in a hospital in 1980.

\section{Haemagglutination tests}

Table II shows the haemagglutination results for all aggregative strains from sporadic cases of diarrhoea

Table II. Haemagglutination (HA) of aggregative E. coli strains

\begin{tabular}{|c|c|c|c|c|c|c|c|c|c|}
\hline \multirow{3}{*}{ Serotype } & \multirow{3}{*}{$\begin{array}{c}\text { Number of } \\
\text { strains* }\end{array}$} & \multicolumn{8}{|c|}{ HA of erythrocytes indicated after growth } \\
\hline & & \multicolumn{4}{|c|}{ in $\mathbf{M H}$ broth } & \multicolumn{4}{|c|}{ on MH agar } \\
\hline & & bovine & $\begin{array}{c}\text { guinea- } \\
\text { pig }\end{array}$ & human & rat & bovine & $\begin{array}{l}\text { guinea- } \\
\text { pig }\end{array}$ & human & rat \\
\hline \multirow[t]{2}{*}{$\mathrm{O} 44: \mathrm{H} 18$} & 6 & - & - & - & MR & - & - & - & MR \\
\hline & 4 & - & - & - & MR & - & - & - & - \\
\hline $\mathrm{O} 111 a b: \mathbf{H} 21$ & 10 & MR & MS & MR & MR & - & MS & - & MS \\
\hline $\mathrm{O} 126: \mathrm{H} 27$ & 13 & MR & - & MR & MR & - & - & MR & MR \\
\hline
\end{tabular}

MS, mannose-sensitive haemagglutination; MR, mannose-resistant haemagglutination; -, no haemagglutination; MH, Mueller Hinton broth or agar.

${ }^{*}$ Three of the six $\mathrm{O} 44: \mathrm{H} 18$ strains are representative strains from the three small outbreaks; all other strains were from sporadic cases of diarrhoea. 
and for one representative $\mathrm{O} 44: \mathrm{H} 18$ strain from each of the above three outbreaks. All strains gave MRHA of rat erythrocytes after growth in broth, but they differed with respect to MRHA of the erythrocytes of other species and in the reactions of solid- or liquidgrown cultures. All O111ab:H21 and O126:H27 strains gave MRHA of bovine and human erythrocytes after growth in broth, although for the latter strains the MRHA of bovine cells was weaker. Only O126:H27 strains consistently gave MRHA when grown on agar and MRHA of rat erythrocytes was stronger than that of human cells.

Non-adhering strains, or those giving LA, gave no haemagglutination or MSHA only. Broth cultures were more likely to give MSHA than agar-grown bacteria, and MSHA of guinea-pig or rat erythrocytes was more common than that of bovine or human erythrocytes. These are characteristics of MSHA due to type-1 fimbriae. The aggregative strains of $\mathrm{O} 44: \mathrm{H} 18$ and $0126: \mathrm{H} 27$ did not show evidence of production of type-1 fimbriae after two passages in broth, whereas all the aggregative strains of O111ab:H21 did.

\section{Tests with strains from healthy children}

The strains isolated from healthy children did not give localised adhesion to HEp-2 cells. Two gave an aggregative pattern of attachment with $>50$ bacteria attaching to a cell in either chains or aggregates. Both were of serogroup 081 ; one was of flagellar-type $\mathrm{H} 27$ and the other was non-motile. Neither hybridised with the EAggEC probe or gave haemagglutination of any of the erythrocyte species tested. Fourteen strains gave diffuse attachment but for only two strains were there $>20$ bacteria attached to each cell.

\section{Discussion}

We have examined strains isolated from infants with diarrhoea in Britain belonging to serotypes $\mathrm{O} 44: \mathrm{H} 18, \mathrm{O} 55: \mathrm{H} 7, \mathrm{O} 111 a b: \mathrm{H} 21, \mathrm{O} 111 a b: \mathrm{H} 25$ and O126: $\mathrm{H} 27$, and have shown that the majority have invitro properties that can be related to diarrhoeagenic ability. Strains of $\mathrm{O} 44: \mathrm{H} 18, \mathrm{O} 111 a b: \mathrm{H} 21$ and O126:H27 were EAggEC as shown by both hybridisation and aggregative attachment to cells in tissue culture. Strains of $\mathrm{O} 55: \mathrm{H} 7$ and $\mathrm{O} 111 a b: \mathrm{H} 25$ had properties characteristic of AEEC - they caused an accumulation of polymerised actin beneath bacteria attached in localised clumps in a tissue-culture test.

Flagellar $(\mathrm{H})$ types are only rarely determined in studies of EPEC and so previous reports on the properties of other bacteria belonging to the serotypes we have examined are few and the numbers of strains studied small. In most of these papers the properties examined were not comprehensive. One O111ab:H21 strain and one O126: $\mathrm{H} 27$ strain have previously been reported to give AggA. ${ }^{27}$ With these two exceptions, other strains belonging to the serotypes shown to be
EAggEC in our study have previously been reported to give DA, DA and LA or to be non-adherent, ${ }^{28-32}$ but several of these studies were performed before AggA was recognised as a distinct pattern. In addition, there is one report of an EAF-positive strain of O126:H27 but the pattern of attachment was not stated. ${ }^{33}$ E. coli $\mathrm{O} 55: \mathrm{H} 7$ strains have been reported to give LA, ${ }^{26,29,30} \mathrm{DA}^{30}$ or no attachment. ${ }^{29-31}$ Strain 660-79 of this serotype was LA-positive, FASpositive ${ }^{11}$ and it colonised cultured duodenal mucosa giving $\mathrm{AE}$ lesions $;^{34}$ it was not stated whether this strain was EAF-positive. Three O55: $\mathrm{H} 7$ strains and one $\mathrm{O} 111 a b: \mathrm{H} 25$ strain have been described that were LA-positive, FAS-positive and EAF-negative ${ }^{27}$ the attachment of all four strains was stated to be poor whereas the 055:H7 strains studied in the present paper attached well. The present work is the first to describe potentially diarrhoeagenic properties for a significant number of strains belonging to these various serotypes.

LA-positive strains of O111ab: $\mathrm{H} 25$, with one exception, attached to a smaller number of HEp-2 cells than $\mathrm{O} 55: \mathrm{H} 7$ strains. Nevertheless, adhesion of bacteria of both serotypes resulted in good fluorescence in the FAS test. Knutton et al..$^{27}$ reported that some strains giving poor LA to tissue-culture cells were able to attach to enterocytes in numbers similar to those achieved by strains giving good LA. Thus, it seems possible that strains of both classes are diarrhoeagenic and the reason for the difference in attachment in vitro is not known. Genes controlling the ability to give good LA are plasmid-encoded in the EAF-positive strain E2348/69 and the EAF-negative O128:H2 strain E25253, ${ }^{7,14,35}$ but the ability to cause actin accumulation after attachment appears to be chromosomally encoded. ${ }^{11,14}$ It will be of interest to see whether the properties of the $055: \mathrm{H} 7$ and O111ab:H25 strains are under similar control and whether a gene-probe recently described for the FAS property ${ }^{36}$ will detect both EAF-positive and EAFnegative EPEC. Certainly, we can conclude that with the use of the EAF probe alone some subclasses of AEEC will not be recognised.

Only two strains isolated in our small study of 32 healthy children in Britain gave AggA and none gave LA. The two aggregative strains, both of serogroup O81, did not hybridise with the EAggEC probe. Previous studies have shown that not all aggregative strains hybridise with the EAggEC probe indicating that these organisms are heterogeneous. ${ }^{18,20} \mathrm{We}$ do not know if the heterogeneity is related to the ability to cause diarrhoea or not. If only some strains giving AggA are pathogenic this may account for the significant numbers isolated from control groups in some epidemiological surveys. Fourteen strains from healthy children gave diffuse attachment; it is still a matter of controversy as to whether strains of $E$. coli that give diffuse attachment can cause diarrhoea. ${ }^{37}$

Our results confirm earlier reports ${ }^{11}$ that EAggEC are negative in the FAS test. An aggregative strain 
(221) isolated from an adult with diarrhoea in Mexico has been shown to cause diarrhoea in adult volunteers. ${ }^{38}$ This strain, like most EAggEC reported to date, did not belong to an EPEC serogroup and was judged to be most closely related to serotype O78: H33/ 35; we have recently shown (unpublished results) that it belongs to serotype O92:H33. In the present study, we have shown that strains belonging to the classic EPEC serotypes O44:H18, O111ab:H21 and O126:H27 may be EAggEC. Most EAggEC have been isolated during studies of infant diarrhoea. Strain 221 was isolated from an adult and some O44:H18 strains in our study were from elderly patients. Methods to identify EAggEC should probably be included in surveys of diarrhoea of all age groups to see if they are a significant cause of such disease.

Nineteen of $40 \mathrm{EAggEC}$ isolated in Chile gave MRHA of human or bovine erythrocytes or both. ${ }^{18}$ Agglutination of rat erythrocytes was not tested. We chose to include rat erythrocytes in the range of bloods studied as Old et al..$^{39}$ had reported that two aggregative strains of serogroup 078 gave MRHA of rat erythrocytes; these strains also agglutinated erythrocytes of several other species. In our study, all of the aggregative strains isolated from the faeces of sick children, but not two strains from healthy children, gave MRHA of rat erythrocytes and, although the

\section{References}

1. Robins-Browne RM. Traditional enteropathogenic Escherichia coli of infantile diarrhea. Rev Infect Dis 1987; 9: 28-53.

2. Cravioto A, Gross RJ, Scotland SM, Rowe B. An adhesive factor found in strains of Escherichia coli belonging to the traditional infantile enteropathogenic serotypes. Curr Microbiol 1979; 3: 95-99.

3. Scaletsky ICA, Silva MLM, Trabulsi LR. Distinctive patterns of adherence of enteropathogenic Escherichia coli to HeLa cells. Infect Immun 1984; 45: 534-536.

4. Nataro JP, Kaper JB, Robins-Browne R, Prado V, Vial P, Levine MM. Patterns of adherence of diarrheagenic Escherichia coli to HEp-2 cells. Pediatr Infect Dis J 1987; 6 : 829-831.

5. Levine MM, Nataro JP, Karch $\mathrm{H}$ et al. The diarrheal response of humans to some classic serotypes of enteropathogenic Escherichia coli is dependent on a plasmid encoding an enteroadhesiveness factor. J Infect Dis $1985 ; 152$ : 550-559.

6. Scotland SM, Willshaw GA, Smith HR, Gross RJ, Rowe B. Adhesion to cells in culture and plasmid profiles of enteropathogenic Escherichia coli isolated from outbreaks and sporadic cases of infant diarrhoea. J Infect 1989; 19: 237-249.

7. McConnell MM, Chart H, Scotland SM, Smith HR, Willshaw GA, Rowe B. Properties of adherence factor plasmids of enteropathogenic Escherichia coli and the effect of host strain on expression of adherence to HEp-2 cells. $J$ Gen Microbiol 1989; 135: 1123-1134.

8. Baldini MM, Nataro JP, Kaper JB. Localization of a determinant for HEp-2 adherence by enteropathogenic Escherichia coli. Infect Immun 1986; 52: 334-336.

9. Smith HR, Scotland SM, Stokes N, Rowe B. Examination of strains belonging to enteropathogenic Escherichia coli serogroups for genes encoding EPEC adherence factor and Vero cytotoxins. J Med Microbiol 1990; 31 : 235-240.

10. Moon HW, Whipp SC, Argenzio RA, Levine MM, Giannella RA. Attaching and effacing activities of rabbit and human enteropathogenic Escherichia coli in pig and rabbit intestines. Infect Immun 1983; 41: 1340-1351. relationship of this property to AggA needs to be confirmed, it may be a useful means of identifying these strains. EAggEC did not give identical patterns of agglutination and, interestingly, the patterns were closely related to the serotype of the strains. As yet, we do not know the reason for these differences.

EPEC remain an important cause of infant diarrhoea in developing countries. In developed countries there has been much discussion as to the continued need to serogroup strains of $E$. coli from children with diarrhoea because the number of serious outbreaks due to these organisms has decreased dramatically in the last 20 years. Nevertheless, some laboratories continue to search for EPEC. It is now possible, using in-vitro tests, as described in this paper, to assign some of these strains to definite classes of diarrhoeagenic $E$. coli. It is probable that alternative tests to those described will be developed soon that will enable clinical laboratories to isolate and identify such strains. We conclude that it is important to identify EPEC strains belonging to the EAggEC and LA-positive FAS-positive EAF-negative classes, as, in Britain, based on the results of this and our earlier communication, ${ }^{9}$ these are probably of greater importance than the LA-positive FAS-positive EAF-positive class.

We thank Mrs A. Thomas for assistance in performing some of the DNA-probe tests.

11. Knutton S, Baldwin T, Williams PH, McNeish AS. Actin accumulation at sites of bacterial adhesion to tissue culture cells: basis of a new diagnostic test for enteropathogenic and enterohemorrhagic Escherichia coli. Infect Immun 1989; 57: 1290-1298.

12. Scotland SM, Willshaw GA, Smith HR, Rowe B. Properties of strains of Escherichia coli $\mathrm{O} 26: \mathrm{H} 11$ in relation to their enteropathogenic or enterohemorrhagic classification. $J$ Infect Dis 1990; 162: 1069-1074.

13. Chart H, Scotland SM, Willshaw GA, Rowe B. HEp-2 adhesion and the expression of a $94 \mathrm{kDa}$ outer-membrane protein by strains of Escherichia coli belonging to enteropathogenic serogroups. J Gen Microbiol 1988; 134: 1315-1321.

14. Scotland SM, Smith HR, Rowe B. Escherichia coli $\mathrm{O} 128$ from infants with diarrhea commonly show localized adhesion and positivity in the fluorescent-actin staining test but do not hybridize with an enteropathogenic $E$. coli adherence factor probe. Infect Immun 1991; 59: 1569-1571.

15. Bhan MK, Khoshoo V, Sommerfelt H, Raj P, Sazawal S, Srivastava R. Enteroaggregative Escherichia coli and Salmonella associated with non-dysenteric persistent diarrhea. Pediatr Infect Dis J 1989; 8: 499-502.

16. Bhan MK, Raj P, Levine MM et al. Enteroaggregative Escherichia coli associated with persistent diarrhea in a cohort of rural children in India. $J$ Infect Dis 1989; 159: 1061-1064.

17. Gomes TAT, Blake PA, Trabulsi LR. Prevalence of Escherichia coli strains with localized, diffuse, and aggregative adherence to HeLa cells in infants with diarrhea and matched controls. J Clin Microbiol 1989; 27 : 266-269.

18. Vial PA, Robins-Browne $\mathrm{R}$, Lior $\mathrm{H}$ et al. Characterization of enteroadherent-aggregative Escherichia coli, a putative agent of diarrheal disease. $J$ Infect Dis $1988 ; 158$ : 70-79.

19. Vial PA, Mathewson JJ, DuPont HL, Guers L, Levine MM. Comparison of two assay methods for patterns of adherence to HEp-2 cells of Escherichia coli from patients with diarrhea. J Clin Microbiol 1990; 28 : 882-885.

20. Baudry B, Savarino SJ, Vial P, Kaper JB, Levine MM. A sensitive and specific DNA probe to identify enteroaggregative Escherichia coli, a recently discovered diarrheal pathogen. J Infect Dis 1990; 161 : 1249-1251. 
21. Scotland SM, Richmond JE, Rowe B. Adhesion of enteropathogenic strains of Escherichia coli (EPEC) to HEp-2 cells is not dependent on the presence of fimbriae. FEMS Microbiol Lett 1983; 20: 191-195.

22. McConnell MM, Chart H, Field AM, Hibberd M, Rowe B. Characterization of a putative colonization factor (PCFO166) of enterotoxigenic Escherichia coli of serogroup O166. J Gen Microbiol 1989; 135: 1135-1144.

23. Willshaw GA, Smith HR, Scotland SM, Rowe B. Cloning of genes determining the production of Vero cytotoxin by Escherichia coli. J Gen Microbiol 1985; 131 : 3047-3053.

24. Willshaw GA, Smith HR, Scotland SM, Field AM, Rowe B. Heterogeneity of Escherichia coli phages encoding Vero cytotoxins; comparison of cloned sequences determining VT1 and VT2 and development of specific gene probes. $J$ Gen Microbiol 1987; 133: 1309-1317.

25. Thomas A, Smith HR, Willshaw GA, Rowe B. Non-radioactively labelled polynucleotide and oligonucleotide DNA probes, for selectively detecting Escherichia coli strains producing Vero cytotoxins VT1, VT2 and VT2 variant. Mol Cell Probes 1991; 5: 129-135.

26. Dorn CR, Scotland SM, Smith HR, Willshaw GA, Rowe B. Properties of Vero cytotoxin-producing Escherichia coli of human and animal origin belonging to serotypes other than O157: H7. Epidemiol Infect 1989; 103: 83-95.

27. Knutton SR, Phillips AD, Smith HR et al. Screening for enteropathogenic Escherichia coli in infants with diarrhea by the fluorescent-actin staining test. Infect Immun 1991; 59: $365-371$.

28. Echeverria P, Taylor DN, Bettelheim KA et al. HeLa celladherent enteropathogenic Escherichia coli in children under 1 year of age in Thailand. J Clin Microbiol 1987; 25 : $1472-1475$.

29. Karch H, Heesemann J, Laufs R. Phage-associated cytotoxin production by and enteroadhesiveness of enteropathogenic Escherichia coli isolated from infants with diarrhea in West Germany. J Infect Dis 1987; 155 : 707-715.

30. Scaletsky ICA, Silva MLM, Toledo MRF, Davis BR, Blake PA, Trabulsi LR. Correlation between adherence to HeLa cells and serogroups, serotypes, and bioserotypes of Escherichia coli. Infect Immun 1985; 49: 528-532.

31. Moyenuddin M, Wachsmuth IK, Moseley SL, Bopp CA, Blake PA. Serotype, antimicrobial resistance, and adherence properties of Escherichia coli strains associated with outbreaks of diarrheal illness in children in the United States. J Clin Microbiol 1989; 27 : 2234-2239.

32. Nataro JP, Scaletsky ICA, Kaper JB, Levine MM, Trabulsi LR. Plasmid-mediated factors conferring diffuse and localized adherence of enteropathogenic Escherichia coli. Infect Immun 1985; 48: 378-383.

33. Gomes TAT, Vieira MAM, Wachsmuth IK, Blake PA, Trabulsi LR. Serotype-specific prevalence of Escherichia coli strains with EPEC adherence factor genes in infants with and without diarrhea in São Paulo, Brazil. J Infect Dis 1989; 160: 131-135.

34. Knutton S, Lloyd DR, McNeish AS. Adhesion of enteropathogenic Escherichia coli to human intestinal enterocytes and cultured human intestinal mucosa. Infect Immun 1987; 55 : 69-77.

35. Baldini MM, Kaper JB, Levine MM, Candy DCA, Moon HW. Plasmid-mediated adhesion in enteropathogenic Escherichia coli. J Pediatr Gastroenterol Nutr 1988; 2: 534-538.

36. Jerse AE, Yu J, Tall BD, Kaper JB. A genetic locus of enteropathogenic Escherichia coli necessary for the production of attaching and effacing lesions on tissue culture cells. Proc Natl Acad Sci USA 1990; 87: 7839-7843.

37. Tacket CO, Moseley SL, Kay B, Losonsky G, Levine MM. Challenge studies in volunteers using Escherichia coli strains with diffuse adherence to HEp-2 cells. $J$ Infect Dis $1990 ; 162$ : 550-552.

38. Mathewson JJ, Johnson PC, DuPont HL, Satterwhite TK, Winsor DK. Pathogenicity of enteroadherent Escherichia coli in adult volunteers. $J$ Infect Dis 1986; 154 : 524-527.

39. Old DC, Tavendale A, Yakubu DE. Some strains of Escherichia coli of putative enteroadherent-aggregative serotypes produce an unusual fibrillar haemagglutinin. FEMS Microbiol Lett 1989; 59: 87-91. 